\title{
FORMATION RATE OF AMMONIUM NITRATE IN THE OFF-GAS LINE OF SRAT AND SME IN DWPF (U)
}

by L. Lee

Westinghouse Savannah River Company

Savannah River Site

Aiken, South Carolina 29808

This paper was prepared in connection with work done under Contract No. DE-AC09-89SR18035 with the U. S. Depariment of Energy. By acceptance of this paper, the publisher and/or recipient acknowledges the U.S. Government's right to retain a nonexclusive, royalty-free license in and to any copyright covering this paper, along with the right to reproduce and to authorize others to reproduce all or part of the copyrighted paper.

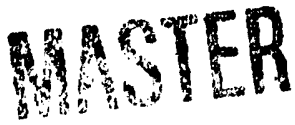




\section{DISCLAIMER}

This report was prepared as an account of work sponsored by an agency of the United States Government. Neither the United States Government nor any agency thereof, nor any of their employees, makes any warranty, express or implied, or assumes any legal liability or responsibility for the accuracy, completeness, or usefulness of any information, apparatus, product, or process disclosed, or represents that its use would not infringe privately owned rights. Reference herein to any specific commercial product, process, or service by trade name, trademark, manufacturer, or otherwise does not necessarily constitute or imply its endorsement, recommendation, or favoring by the United States Government or any agency thereof. The views and opinions of authors expressed herein do not necessarily state or reflect those of the United States Govemment or any agency thereof.

This report has been reproduced directly from the best available copy.

Available to DOE and DOE contractors from the Oifice of Scientific and Technical Information, P.O. Box 62, Oak Ridge, TN 37831; prices available from (615) 576-8401, FTS 626-8401.

Available to the public from the National Technical Information Service, U.S. Department of Commerce, 5285 Port Royal Rd., Springfield, VA 22161. 
Westinghouse Savannah River Company Savannah River Laboratory

To: L. F. Landon, 7045-T

WSRC-RP-92-346

Keywords: Ammonium Nitrate Ammonia, SRAT, SME, Mathematical Model

Retention Period: Permanent

CC E. W. Holtzscheiter, 773-A

C. T. Randall, 704-T

J. T. Carter, 704-1 T

N. Hutson, 704-1 T

J. R. Zamecnik, 704-1T

R. A. Jacobs, 704-T

C. W. Hsu, 704-1T

J. C. Marek, 704-T

PMC File, 704-T

SRL Records (4)

From: L. Lee, 704-T Lee

February 25, 1992

\section{FORMATION RATE OF AMMONIUM NITRATE IN THE OFE-GAS LINE OF SRAT AND SME IN DWPF (U)}

\section{I: SUMMARY:}

A mathematicai model for the formation rate of ammonium nitrate in the off-gas line of the Sludge Receipt and Adjustment Tank (SRAT) and the Slurry Mixed Evaporator (SME) in DWPF has been developed. The formation rate of ammonium nitrate in the off-gas line depends on $\mathrm{pH}$, temperature, volume and total concentration of ammonia and ammonium ion. Based on a typical SRAT and SME cycle in DWPF, this model predicts the SRAT contributes about $50 \mathrm{lbs}$ of ammonium nitrate while SME contributes about $60 \mathrm{lbs}$ of ammonium nitrate to the off-gas line.

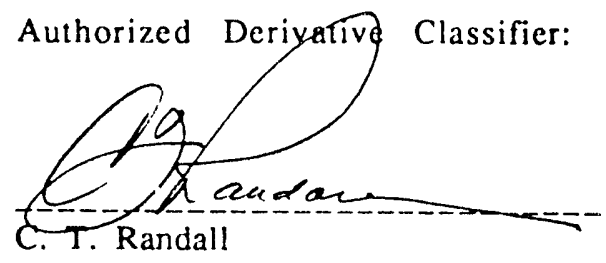


This report provides a preliminary ammonium nitrate formation rate expected during the melter feed preparation cycles. These data may serve as a preliminary design basis for the scrubber jumpers to be installed in the Chemical Processing Cell (CPC) to mitigate ammonium nitrate accumulation downstream of the HEME. The accuracy of this model will be tested by comparing it with data obtained from coming IDMS experiments.

\section{DETAIL:}

Feeds to the SRAT and SME contain ammonia and ammonium ion. Under the feed preparation conditions some of this ammonia may vaporize from the SRAT and SME and react with NOx in the off-gas line and lead to deposition of ammonium nitrate in the vapor line. When the solution $\mathrm{pH}$ is below 6 most of the ammonia exists as ammonium ion, which is nonvolatile. But if the solution $\mathrm{pH}$ is above 9 most of the ammonium ion converts to free ammonia, which is easily vaporized under the process conditions. The volatilized ammonia reacts with NOx in the off-gas and forms ammonium nitrate deposits. Therefore, it is obvious that the formation rate of ammonium nitrate in the off-gas line is highly $\mathrm{pH}$ dependent. To minimize the deposition of ammonium nitrate, it is desirable to keep the SRAT and SME at a pH as low as achievable. As an indicator of ammonia volatility, the percent free ammonia as a function of solution $\mathrm{pH}$ is given in Figure 1. The equations which lead to Figure 1 are summarized in Appendix $I$.

Figure 2 gives ammonia partial pressure, in $\mathrm{mm} \mathrm{Hg}$, as a function of solution $\mathrm{pH}$ and temperature. It is readily seen that the ammonia partial pressure increases with solution $\mathrm{pH}$ and temperature. The increase is far more $\mathrm{pH}$ dependent than temperature dependent. This reaffirmed the previous conclusion that to minimize ammonium nitrate deposition in the off-gas line, it is imperative to keep the solution $\mathrm{pH}$ at the minimum possible value.

Figure 3 gives the mass transfer coefficient of ammonia from the liquid interface into the vapor space as a function of solution temperature. The strength of natural convection increases as the solution temperature increases. Therefore, the ammonia mass transfer coefficient increases with solution temperature. The increase is much more pronounced at low temperatures than at higher temperatures as expected. 
FIGURE 1: PERCENT FREE AMMONIA

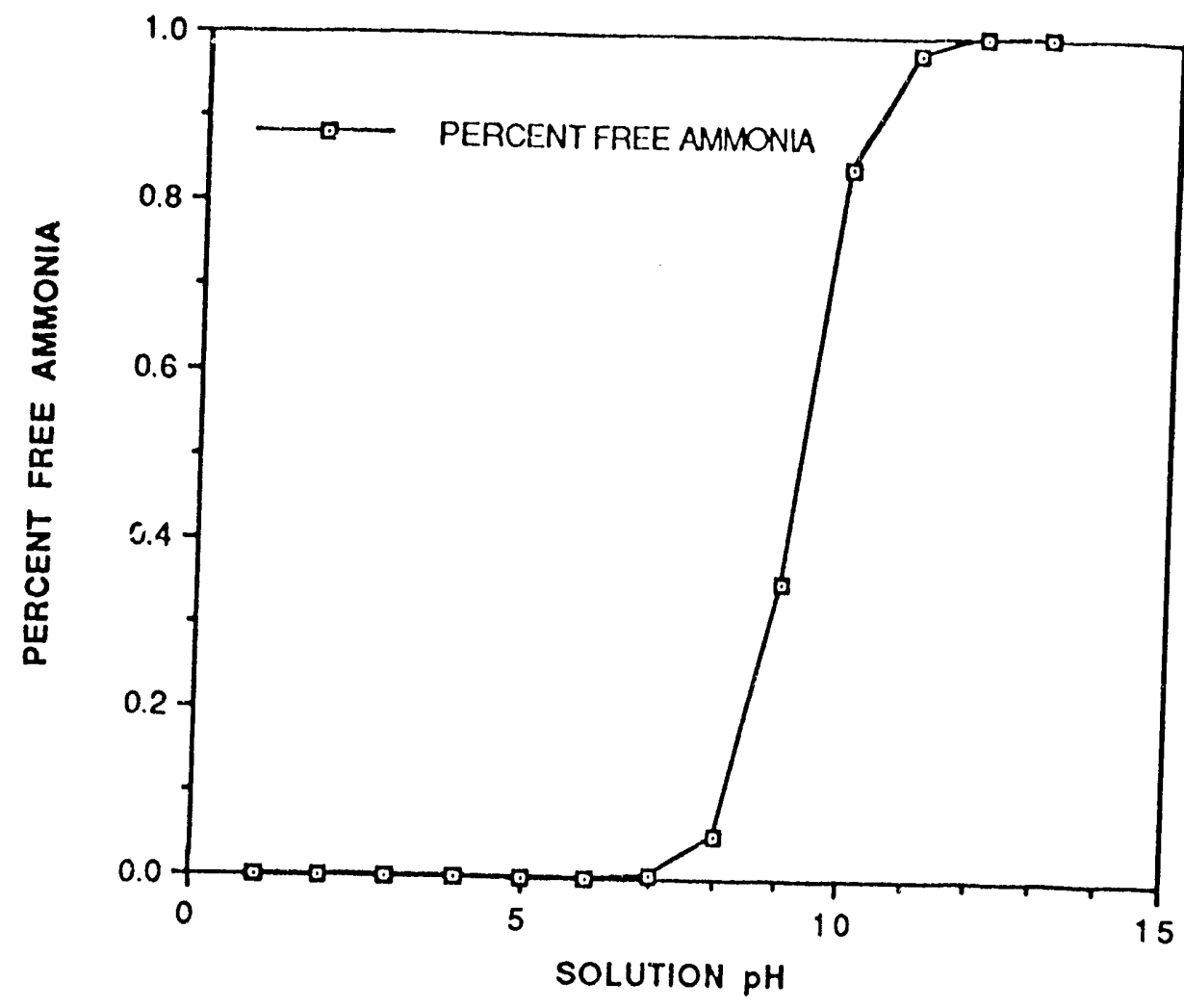

FIGURE 2: NH3 PARTIAL PRESSURE, MM Hg. AT 1000 PPM TOTAL AMMONIUM ION CONC

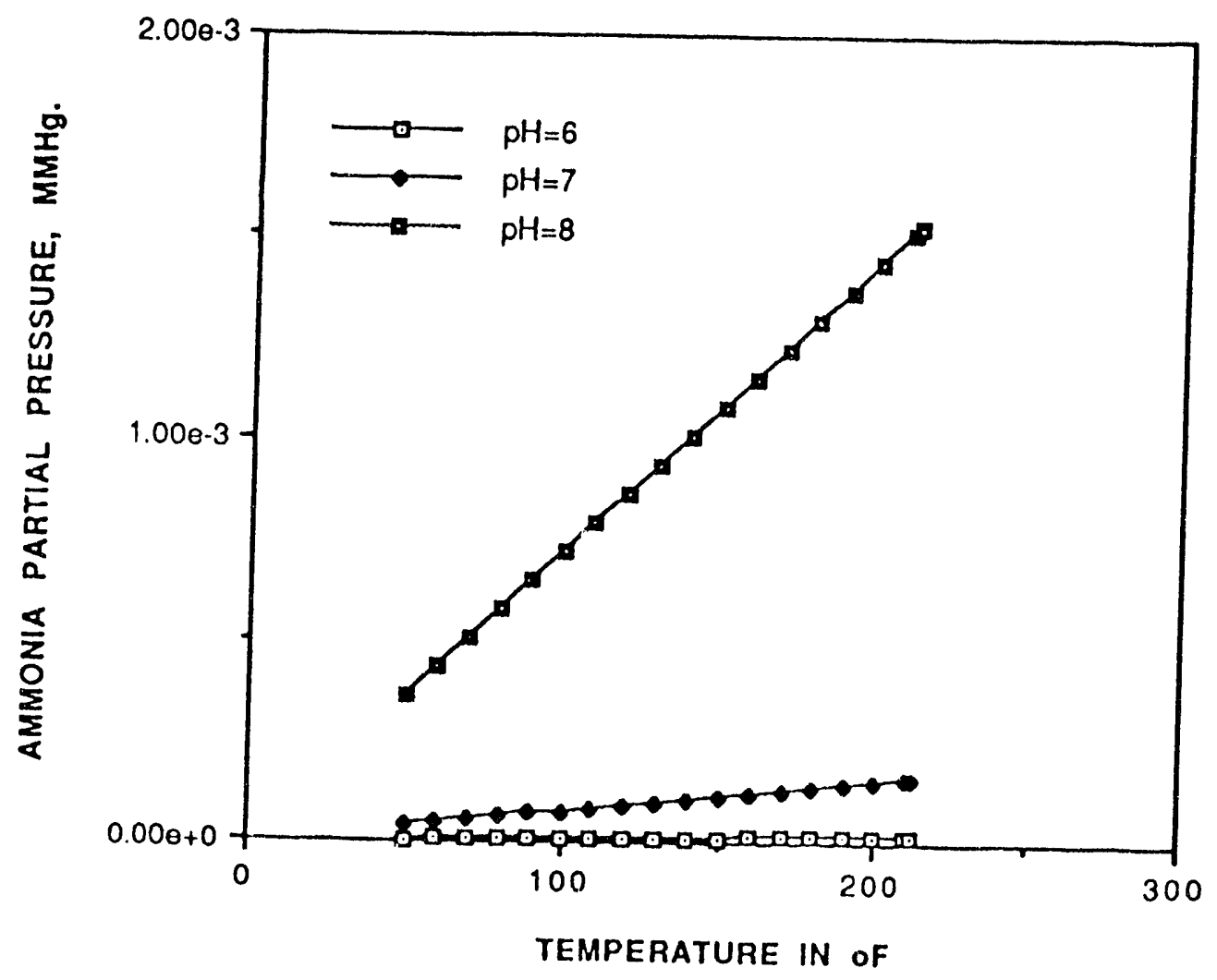


FIGURE 3: MASS TRAHSFER COEFFICIENT FOR AMMONIA IN LB-MOLE/FT^2/HR

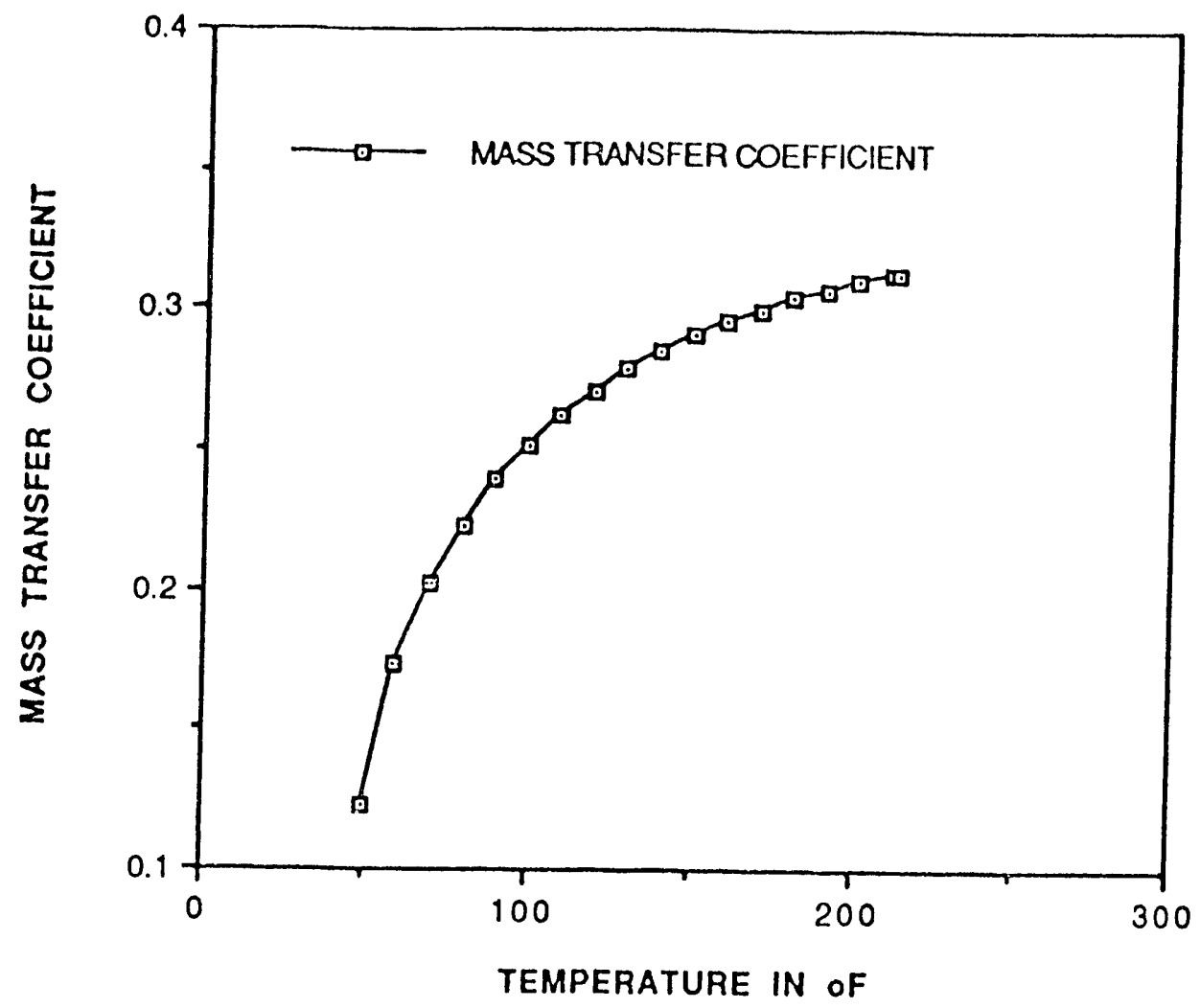

FIGURE 4: SRAT PH AND TEMPERATURE AS FUNCTION OF TIME

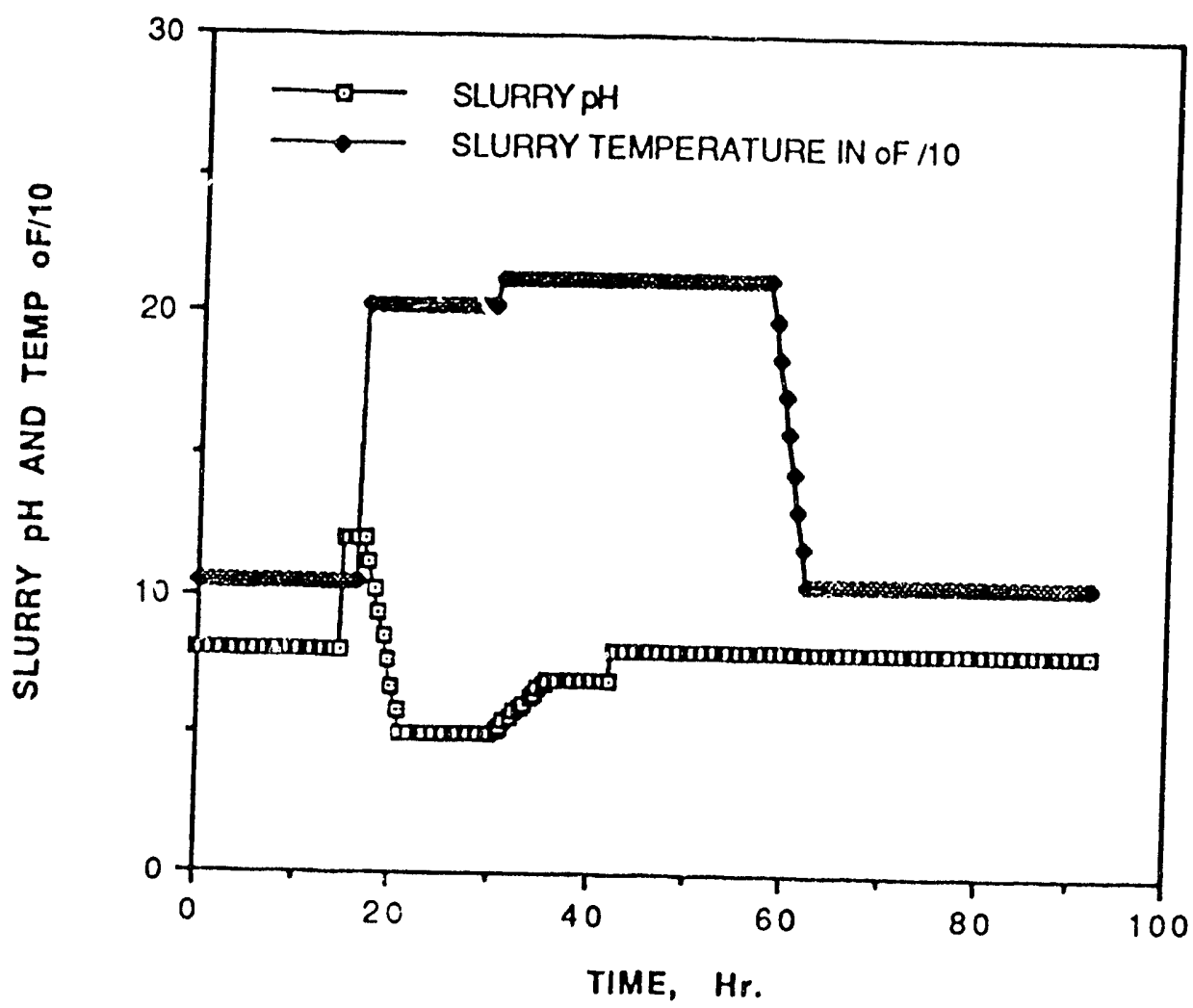


Figure 4 gives detailed $\mathrm{pH}$ and temperature profiles for the SRAT during a typical cycle. The $\mathrm{pH}$ of the heel is about 8; it increases to about 12 when a new batch of sludge is mixed with the heel. The $\mathrm{pH}$ is then reduced to about 5 during formic acid addition and maintained at that value during PHA addition. The $\mathrm{pH}$ rises slowly during refiluxing and boil off; this is caused by decomposition of formic acid. It reaches a value of about 8 after the cycle. The temperature and the $\mathrm{pH}$ share the same scale because the temperature values on the figure have been reduced by a factor of 10 .

With the temperature and $\mathrm{pH}$ profiles given in Figure 4, with $960 \mathrm{ppm}$, $300 \mathrm{ppm}$ and $1500 \mathrm{ppm}$ of ammonium ion in the heel, sludge and PHA, respectively, the total ammonium nitrate deposited in the off-gas line is about $50 \mathrm{lbs}$. The final ammonium concentration in the SRAT is about $960 \mathrm{ppm}$. Figure 5 gives the total amount of ammonium nitrate deposited in the off-gas line as a function of SRAT processing time. The $\mathrm{pH}$ profile during the SRAT cycles are superimposed to show the sensitivity of ammonium nitrate deposition rate to the the solution $\mathrm{pH}$.

Figure 6 gives the total ammonium nitrate deposition in the SME offgas line as a function of time. To give a higher estimation of ammonium nitrate deposition rate, the $\mathrm{pH}$ of $\mathrm{SME}$ is assumed to be 9 throughout the cycle. The initial and the final ammonium nitrate deposition rates are slow because the total ammonium ion concentration is very low, only about $6 \mathrm{ppm}$. When a new batch of feed from the SRAT containing about $960 \mathrm{ppm}$ of ammonium ion is added into the SME the ammonium nitrate deposition rate takes off immediately. The rate gradually tappers off as the total ammonium ion concentration is depleted. The final ammonium ion concentration in the finished SME is only about $6 \mathrm{ppm}$. The ammonium nitrate deposits in the off-gas line resulting from the SRAT and the SME cycle are about 50 and $60 \mathrm{lbs}$, respectively. Therefore, the total ammonium nitrate deposition from a complete feed preparation cycle is about 110 lbs.

The derivation of the mathematical model is given in Appendix $I$. BASIC programs based on the model are given in Appendix II for the SRAT and Appendix III for the SME. 
FIGURE 5: SLURRY PH AND TOTAL NHANO3 DEPOSITED IN THE VAPOR LINE (SRAT)

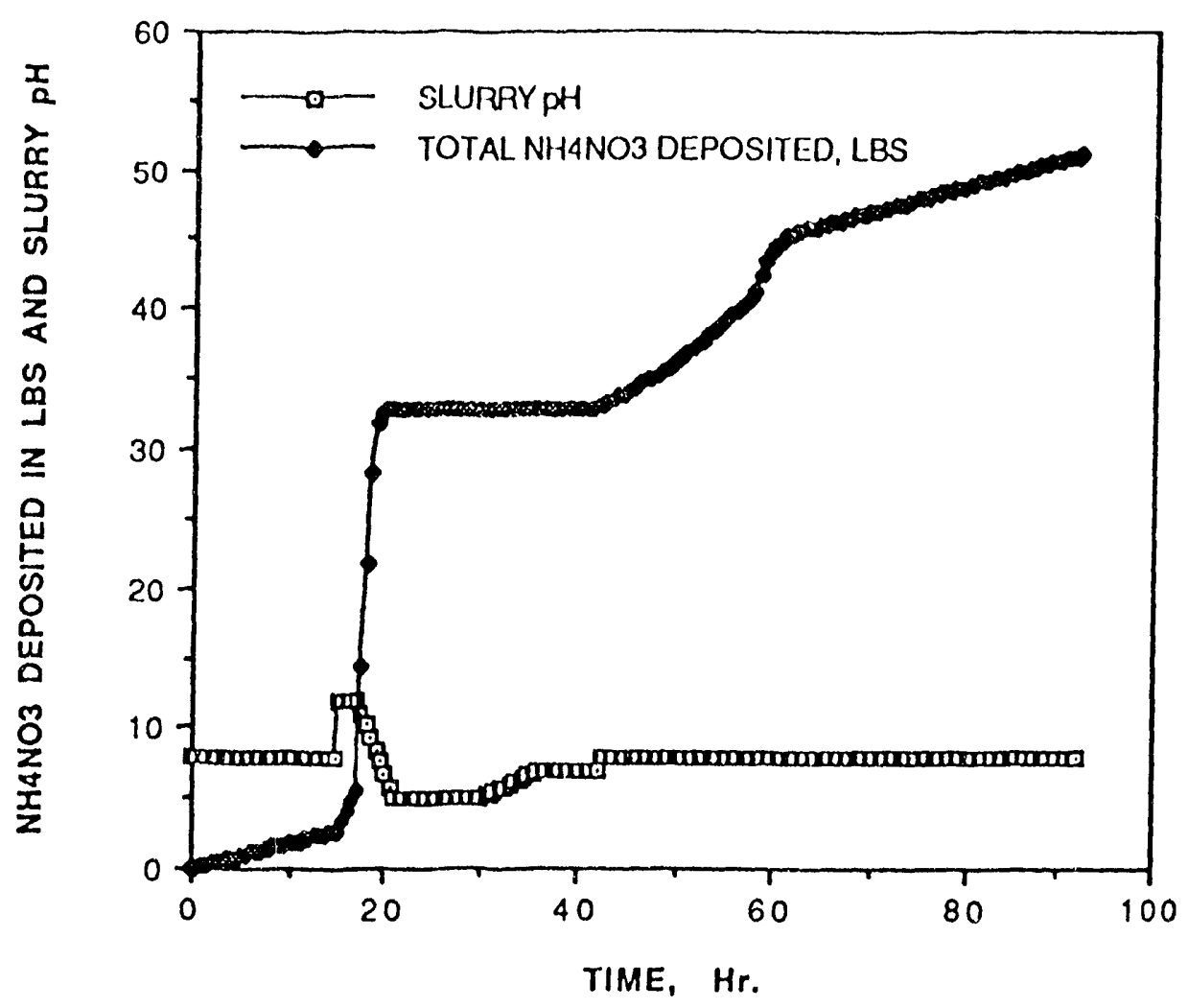

FIGURE 6: TOTAL NH4NO3 DEPOSITED IN THE VAPOR LINE (SME)

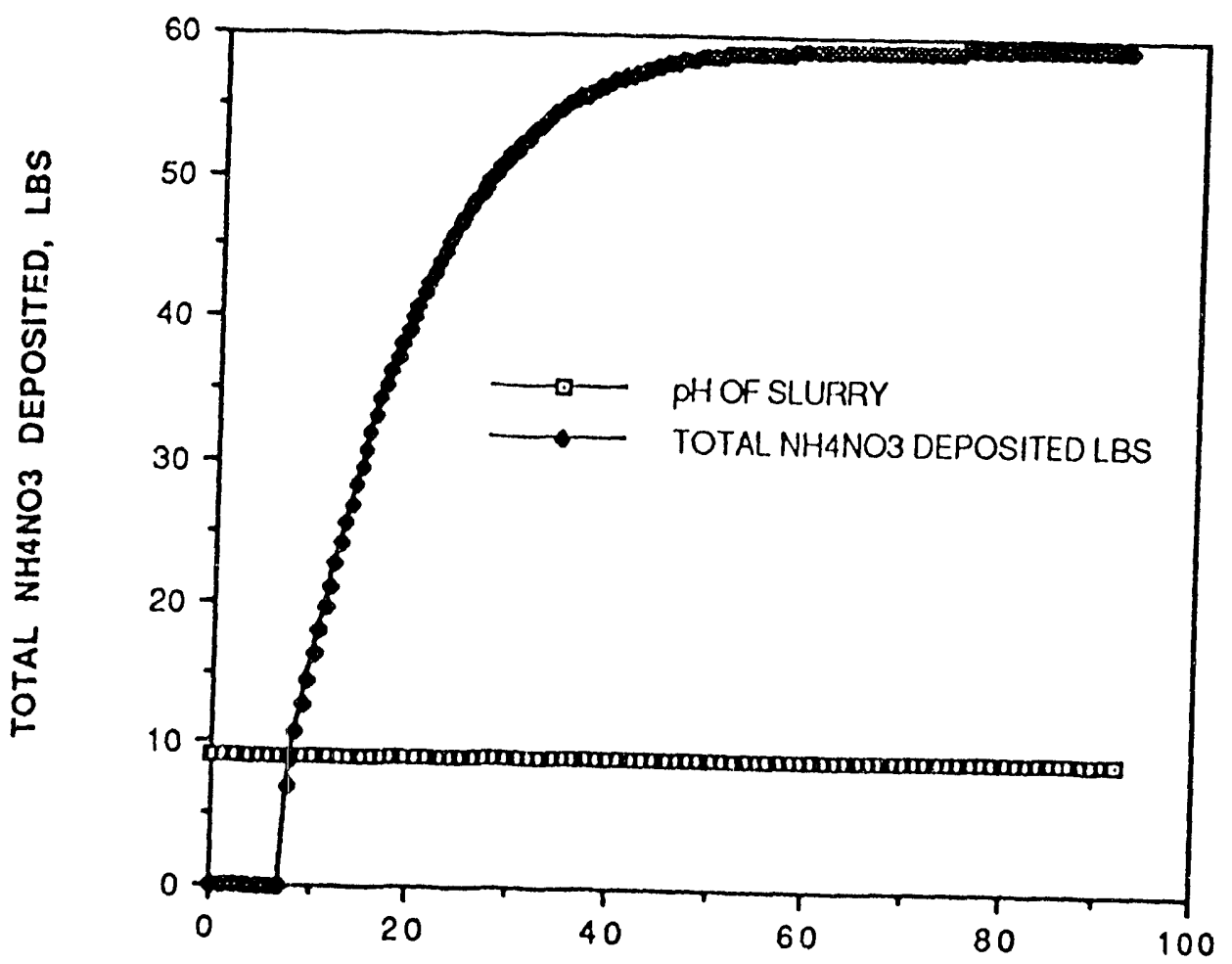

TIME, Hr. 


\section{QUALITY ASSURANCE:}

The computer subroutine used to solve simultaneous differential and algebraic equations has been tested with problems with known answers and the agreement are excellent. The physical properties of the system such as Henry's constant, ionization constant of ammonia are taken from Perry's Chemical Engineering Handbook and CRC Handbook, both are respectable data sources. The mass transfer coefficient for ammonia in the vapor space are calculated based on Colburn's heat and mass transfer analogy which is a well accepted practice in chemical engineering calculations. Finally, the calculated results will be compared with the upcoming IDMS data to verify the accuracy of the model.

\section{APPENDIX I: MATHEMATICAL MODEL FOR AMMONIA VOLATILITY FROM DWPF FEED PREPARATION CYCLE}

\section{CHEMICAL EQUILIBRIUM OF AMMONIA IN WATER:}

The chemical equilibrium of ammonia in water can be represented by $\mathrm{Eq}(1)$.

$$
\mathrm{NH}_{3}+\mathrm{H}_{2} \mathrm{O}=\mathrm{NH}_{4}+\mathrm{OH}
$$

According to the mass action law, the equilibrium can be expressed by $\mathrm{Eq}(2)$.

$$
\left[\mathrm{NH}_{4}\right][\mathrm{OH}] /[\mathrm{NH} 3]=\mathrm{Kb}
$$

$\mathrm{Kb}=$ the ionization constant for ammonia in water. Let $\mathrm{T}_{0}=$ total ammonium ion and ammonia concentration in $l b-m o l e / \mathrm{ft}^{\wedge} 3$ and $M=$ free ammonia concentration. Then $\mathrm{Eq}(2)$ can be rewritten as:

$$
\left(\mathrm{T}_{\mathrm{o}}-\mathrm{M}\right)[\mathrm{OH}] / \mathrm{M}=\mathrm{Kb}
$$

Taking logarithm of $\mathrm{Eq}(3)$ and substituting $(\mathrm{pH}-14)$ for $\log [\mathrm{OH}], \mathrm{pKb}$ for $-\log (\mathrm{Kb})$ and $\mathrm{Ps}$ for $\mathrm{pKb}+\mathrm{pH}-14 \mathrm{Eq}(3)$ becomes:

$$
\begin{aligned}
& \log \left\{M /\left(T_{o}-M\right)\right\}=P_{s} \\
& P_{s}=p K b+p H-14
\end{aligned}
$$


$\mathrm{pKb}$ of ammonia in water are taken from the 64th edition of CRC Handbook D-169, and can be represented by Eq(6).

$$
\mathrm{pKb}=5.2209-0.24448 * \log (\mathrm{T})
$$

$\mathrm{T}=$ solution temperature is $\mathrm{oF} . \mathrm{Eq}(4)$ can be rearranged to give $\mathrm{Eq}(5)$, mole fraction of free ammonia.

$$
\mathrm{M} / \mathrm{T}_{\mathrm{o}}=10^{\wedge} \mathrm{Ps} /\left(1+10^{\wedge} \mathrm{Ps}_{\mathrm{s}}\right)
$$

Figure 1 gives percent of free ammonia as a function of $\mathrm{pH}$, which is a graphical representation of $\mathrm{Eq}(5), \mathrm{Eq}(6)$ and $\mathrm{Eq}(7)$.

\section{PARTIAL PRESSURE OF AMMONIA:}

Partial pressure of ammonia can be calculated by Henry's law, which is given in $\mathrm{Eq}(8)$.

$$
\mathrm{P}=\mathrm{HX}
$$

where, $\mathrm{P}=$ partial pressure of ammonia in $\mathrm{mm} \mathrm{Hg}, \mathrm{H}=$ Henry's constant also in $\mathrm{mm} \mathrm{Hg}$ and $\mathrm{X}$ is mole fraction of free ammonia in the solution. Henry's constant for ammonia in water is taken from the 6 th edition of Perry's Chemical Engineering Handbook p 3-101 and can be represented by $\mathrm{Eq}(9)$.

$$
\mathrm{H}=137.84 * 10^{\wedge}(0.009622 * \mathrm{~T})
$$

The mole fraction of free ammonia in the solution can be obtained from $\mathrm{Eq}(7)$ and is given in $\mathrm{Eq}(10)$.

$$
\mathrm{X}=(18 / 62.4) *\left[10^{\wedge} \mathrm{P}_{\mathrm{s}} /\left(1+\mathrm{P}_{\mathrm{s}}\right)\right] * \mathrm{~T}_{\mathrm{o}}
$$

Figure 2 gives the partial pressure of ammonia in $\mathrm{mm} \mathrm{Hg}$ as a function of solution temperature in oF, which is a graphical representation of $\mathrm{Eq}(8), \mathrm{Eq}(9)$ and $\mathrm{Eq}(10)$.

\section{MASS TRANSFER COEFFICIENT OF AMMONIA IN THE VAPOR SPACE:}

The SRAT and SME are assumed to be well-mixed so that the resistance to mass transfer is only limited by the vapor phase. The vapor phase mass transfer coefficient is estimated based on the heat and mass 
transfer analogy of Colburn (see Perry's Chemical Engineering Handbook p 14-14).

$$
(\mathrm{KG} / \mathrm{Gm}) *(\mathrm{UG} / \mathrm{PG} / \mathrm{D}) \wedge(2 / 3)=\left(\mathrm{h} / \mathrm{C}_{\mathrm{p}} / \mathrm{G}\right) *\left(\mathrm{Pr}_{\mathrm{r}}\right) \wedge(2 / 3)
$$

where, $\quad K G=$ mass transfer coefficient in $\mathrm{lb}-\mathrm{mole} / \mathrm{ft}^{\wedge} 2 / \mathrm{hr}$

$\mathrm{Gm}=$ molar mass velocity in $\mathrm{lb}-\mathrm{mole} / \mathrm{ft}^{\wedge} 2 / \mathrm{hr}$

$\mathrm{UG}_{\mathrm{G}}=$ viscosity of air in $\mathrm{lb} / \mathrm{ft} / \mathrm{hr}$

$\mathrm{PG}_{\mathrm{G}}=$ density of air in $\mathrm{lb} / \mathrm{ft}^{\wedge} 3$

$\mathrm{D}=$ diffusivity of ammonia in air in $\mathrm{ft} / \mathrm{hr} / \mathrm{hr}$

$\mathrm{h}=$ heat transfer coefficient in $\mathrm{Btu} / \mathrm{f} \mathrm{t}^{\wedge} 2 / \mathrm{hr} / \mathrm{oF}$

$\mathrm{C}_{\mathrm{p}}=$ heat capacity of air in Btu/lb

$\mathrm{G}=$ mass velocity in $\mathrm{lb} / \mathrm{ft}^{\wedge} 2 / \mathrm{hr}$

$\operatorname{Pr}=$ Prandtl number for air which is 0.69 .

Substituting all known properties of the system into Eq(11), it may be simplified to $\mathrm{Eq}(12)$, a relationship between the heat transfer coefficient and the mass transfer coefficient.

$$
\mathrm{KG}=0.2661 \mathrm{~h}
$$

Therefore, if the heat transfer coefficient for natural convection is known, the mass transfer coefficient can be calculated from $\mathrm{Eq}(12)$. The natural convective heat transfer coefficient for the vapor phase is given by $\mathrm{Eq}(13)$.

$$
(\mathrm{h} * \mathrm{~d} / \mathrm{k})=0.15 *\left(\mathrm{Gr}^{*} \mathrm{Pr}\right)^{\wedge}(1 / 3)
$$

where, $\quad d=$ diameter of the vessel in $\mathrm{ft}$

$\mathrm{k}=$ thermal conductivity of air in $\mathrm{Btu} / \mathrm{ft} / \mathrm{hr} / \mathrm{oF}$

$\mathrm{Gr}=$ Grasof's number

Figure 3 gives the mass transfer coefficient of ammonia in the vapor space as a function of solution temperature, which is a graphical representation of $\mathrm{Eq}(12)$ and $\mathrm{Eq}(13)$.

\section{MATHEMATICAL EQUATION FOR AMMONIA VOLATILITY:}

Three assumptions are made to simplify the formulation of the model, and they are:

1. Liquid phase is well-mixed. 
2. For conservative estimation, the concentration of $\mathrm{NH}_{3}$ in the bulk vapor phase is negligible.

3. There is equilibrium for $\mathrm{NH}_{3}$ between the vapor phase and the liquid phase in the condenser, ie. condenser behaves as an equilibrium stage.

With these assumptions, the material balance for the liquid phase is given in $\mathrm{Eq}(14)$.

$$
\mathrm{V}^{*}(\mathrm{dC} \mathrm{l} / \mathrm{dt})=-\mathrm{KG}^{*} \mathrm{~A} *\left(\mathrm{P} / \mathrm{P}_{\mathrm{t}}\right)+\mathrm{F} * \mathrm{CF}+\mathrm{E} * \mathrm{R} * \mathrm{C}_{2}
$$

where, $\quad V=$ liquid volume, function of time in $\mathrm{ft}^{\wedge} 3$

$\mathrm{E}=$ liquid evaporation rate, $\mathrm{ft}^{\wedge} 3 / \mathrm{hr}$

$\mathrm{F}=$ liquid feed rate, $\mathrm{ft}^{\wedge} \mathrm{3} / \mathrm{hr}$

$\mathrm{C}_{1}=$ concentration of total ammonium ion and ammonia in the liquid phase in $\mathrm{lb}-\mathrm{mole} / \mathrm{ft}^{\wedge} 3$.

$\mathrm{C}_{2}=$ concentration of total ammonium ion and ammonia in the condensate in $\mathrm{lb}-\mathrm{mole} / \mathrm{ft}^{\wedge} 3$.

$\mathrm{CF}=$ concentration of total ammonium ion and ammonia in the liquid feed in lb-mole/ft^3.

$R=$ is an index when the pot is boiling. $R=1$ during refluxing , $\mathrm{R}=-1$ during boil down and $\mathrm{R}=0$ for other conditions.

$\mathrm{Pt}_{\mathrm{t}}=$ total pressure in the vapor phase in $\mathrm{mm} \mathrm{Hg}$.

$\mathrm{t}=$ time in $\mathrm{hr}$.

$\mathrm{A}=$ cross sectional area for the pot in $\mathrm{Ft}^{\wedge} 2$.

The partial pressure of ammonia is given by $\mathrm{Eq}(15)$.

$$
\mathrm{P}=\mathrm{H} * \mathrm{X}
$$

Mole fraction of free ammonia is given in $\mathrm{Eq}(16)$.

$$
\mathrm{X}=(18 / 62.4) *\left\{10^{\wedge} \mathrm{Ps}_{\mathrm{s}} /\left(1+10^{\wedge} \mathrm{P}_{s}\right)\right\} * \mathrm{C}_{1} \text { (16) }
$$

$\mathrm{Eq}(14), \mathrm{Eq}(15)$ and $\mathrm{Eq}(16)$ are simuitaneous differential and algebraic equations which are solved by the Generalized Runge-Kutta's method. Detailed BASIC programs for this method are given in Appendix II and Appendix III. During boil down and refluxing the following equations for the condenser are required.

The material balance for the condenser during boil down or refluxing is given in $\mathrm{Eq}(17)$. 


$$
\mathrm{C}_{2} * \mathrm{E}+\mathrm{FA}^{*} *\left(\mathrm{P}^{\prime} / \mathrm{Pt}_{\mathrm{t}}\right)=\mathrm{KG}^{*} \mathrm{~A}^{*}\left(\mathrm{P} / \mathrm{Pt}_{\mathrm{t}}\right)
$$

where, $\quad F_{A}=$ air flow rate through the condenser in $\mathrm{lb}-\mathrm{mole} / \mathrm{hr}$. $\mathrm{P}^{\prime}=$ ammonia partial pressure in the condenser, $\mathrm{mm} \mathrm{Hg}$.

The partial pressure of ammonia in the condenser is given by $\mathrm{Eq}(18)$, which is Henry's law.

$$
\mathrm{C}_{2} /(62.4 / 18) * \mathrm{H}^{\prime}=\mathrm{P}^{\prime}
$$

Henry's constant for ammonia in the condenser is given in Eq(19).

$$
\mathrm{H}^{\prime}=137.84 * 10^{\wedge}\left(0.009622 * \mathrm{~T}^{\prime}\right)
$$

where, $\quad H^{\prime}=$ Henry's constant in condenser.

$\mathrm{P}^{\prime}=$ partial pressure of ammonia in condenser in $\mathrm{mm} \mathrm{Hg}$. $\mathrm{T}^{\prime}=$ temperature at condenser, oF .

The concentration of total ammonia and ammonium ion in the condensate $\mathrm{C}_{2}$ may be obtained analytically from $\mathrm{Eq}(17)$ and $\mathrm{Eq}(18)$ and it is given in $\mathrm{Eq}(20)$.

$$
\mathrm{C}_{2}=\mathrm{KG} * \mathrm{~A} *\left(\mathrm{P} / \mathrm{Pt}_{\mathrm{t}}\right) /\left(\mathrm{E}+\mathrm{FA}^{*} 18 / 62.4 * \mathrm{H}^{\prime} / \mathrm{Pt}_{\mathrm{t}}\right)
$$

During refluxing or boil down $\mathrm{Eq}(20)$ is used with $\mathrm{Eq}(14), \mathrm{Eq}(15)$ and $\mathrm{Eq}(16)$ for ammonia volatility calculation. 


\section{APPENDIX II: BASIC PROGRAM FOR SRAT NH3 VOLOATILITY}

10 'THIS PROGRAM CALCULATE AMMONIA VOLATILITY RATE

20 'ALL UNITS ARE BRITISH UNITS EXCEP'T PRESSURE IN $\mathrm{mmHg}$

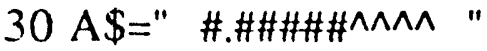

40 DEFINT I-P

$50 \mathrm{~N}=3$ 'TO'TAL NUMBER OF EQUATION

60 'DEFINT I-P : DEFDBL A-H,Q-Z

70 DIM

$A(N, N), B(N), C(N), D(N, N), C 0(N), P(N), X(N), X P(N), A K 1(N), A K 2(N), A K 3(N), F$ $(\mathrm{N}, 2)$

71 OPEN "O",\#1,"SRATDATA"

$S O$ 'READ IN THE PROCESS VARIABLES

90 'PH; TOTAL AMMONIA,PPM; SOLUTION TEMP, oF; TANK

DIAMETER, FT; TOTAL PRESSURE, MMHG; SOLUTION VOLUME, FT^3;

COND. TEMP, oF; AIR PURGE, LB-MOLE/HR; LP

100 READ APH ,APPMT0,TEMP,DIA,APT,V,TEMPP, AIR,? P

110 DATA $8,960,104,12,745,240.3,104,40.43,0$

$120 \mathrm{E}=0$ 'EVAPORATION RATE FT^3/HR

$130 \mathrm{FR}=0$ 'FLOW RATE FT^3/HR

$140 \mathrm{CF}=0$ 'CONC OF TOTAL AMMONIUM IN THE FEED LB-MOLE/FT^3 150 'CALCULATE PROCESS PROPERTIES

160 A.PKB $=5.2209-.24448 / 2.303 *$ LOG(TEMP) ' PKB OF AMMONIA IN

THE SRAT

170 APKBP=5.2209-.24448/2.303*LOG(TEMPP) ' PKB OF AMMONIA N THE CONDENSER

$180 \mathrm{AH}=137.84 * 10^{\wedge}(.009622 *$ TEMP $)$ 'HENRY'S CONSTANT MMHG IN THE SRAT

190 AHP $=137.84 * 10^{\wedge}(.009622 *$ TEMPP $)$ 'HENRY'S CONSTANT IN CONDENSER MMHG

$200 \mathrm{G}=32.2 * 3600 * 3600$ 'GRAVITATIONAL ACCELERATION CONSTANT $\mathrm{FT} / \mathrm{HR} / \mathrm{HR}$

$210 \mathrm{BETA}=1 /(460+\mathrm{TEMP})$ 'IDEAL GAS EXPANSION COEFFICIENT

$220 \mathrm{TA}=65 \quad$ 'AIR TEMPERATURE oF

$230 \mathrm{ZOG}=29 / 359 * 492 /(\mathrm{TA}+460) * \mathrm{APT} / 760$ 'AIR DENSITY LB/FT^3

$240 \mathrm{UG}=.04356 *((\mathrm{TA}+460) /(460+100))^{\wedge} .5$ 'AIR VISCOSITY 0.04356

LB/FT/HR AT 100 oF

250 APR $=.69^{\prime}$ AIR PRANDTL NUMBER

$2.50 \mathrm{SC}=.61$ 'SCHMIDT NUMBER FOR AMMONIA IN AIR

$270 \mathrm{CP}=.24$ 'SPECIFIC HEAT OF AIR BTU/LB/OF

280 AK $=.014 *((T A+460) /(460+32))^{\wedge} .5$ 'AIR THERMOCONDUCTIVITY

B TU/HR/FT/oF

290 AREA $=3.14 *$ DIA*DIA/4 ' SOLUTION SURFACE AREA, FT^2 
$300 \mathrm{GR}=\mathrm{G}^{*} \mathrm{BETA}^{*}(\mathrm{TEMP}-\mathrm{TA}) * \mathrm{DIA}^{\wedge} 3 *^{\prime} \mathrm{ZOG}^{\wedge} 2 / \mathrm{UG}^{\wedge} 2{ }^{\prime}$ GRASOF NUMBER $310 \mathrm{HC}=\mathrm{AK} / \mathrm{DIA} * .15^{*}\left(\mathrm{GR}^{*} .69\right)^{\wedge}(1 / 3)$ 'HEAT 'TRANSFER COEFFICIENT BTU/FT/HR/oF

320 APS $=$ APKB + APH -14

$330 \mathrm{X}(1)=$ APPMT0/1000000!*62.4/18 'lb-1/10le/ft^3 total ammonium $340 \times(3)=18 / 62.4 * 10^{\wedge}$ APS $/\left(1+10^{\wedge}\right.$ APS $) * X(1)^{\prime}$ MOLE FRACTION OF FREE AMMONIA $350 \mathrm{X}(2)=\mathrm{AH} * \mathrm{X}(3)$ 'VAPOR PRESSURE OF AMMONIA IN IN SRAT IN MMHG $360 \mathrm{AKG}=.2661{ }^{*} \mathrm{HC}^{\prime}$ MASS TRANSFER COEF FICIENT LB-MOLE/FT^2/HR 370 PRINT " LBS AMMONIA CONDENSATE PH .

380 PRINT " TIME. HR PPMT EVAPORATED VAPOR LINE " 390 'INPUT INITIAL CONDITIONS, STEP SIZE AND TIME LIMIT

$400 \mathrm{~T}=0: \mathrm{H}=.5: \mathrm{RT}=92$

410 'INPUT BASIC CONSTANTS FOR GSIRK

$420 \quad \mathrm{~A} 1=.435867 \quad: \mathrm{B} 2=.75 \quad: \mathrm{B} 31=-.630172 \quad: \mathrm{B} 32=-.24235$ :

$\mathrm{R} 1=1.03758: \mathrm{R} 2=.83494$

430 'INPUT D MATRIX

$440 \mathrm{D}(1,1)=1$

450 '

$460^{\prime}$

470 '

480 GOTO 940 'PRINT OUT INITIAL CONDITIONS

490 'CALCULATE FIRST B MATRIX AND JACOBIAN

$500 \mathrm{~J}=1$

510 GOSUB 1410 'EQUATIONS TO BE SOLVED IN F(I,J)=F(X,T)

$520 \mathrm{~J}=2$

530 FOR I $=1$ TO N

$540 \mathrm{~B}(\mathrm{I})=\mathrm{F}(\mathrm{I}, 1) * \mathrm{H}$ 'THE FIRST B MATRIX

$550 \mathrm{DXJ}=\mathrm{X}(\mathrm{I}) * .0001$ 'X(I) INCREMENT

$560 \mathrm{IF}$ DXJ $=0$ THEN DXJ $=.00001$ 'ALTERNATE $X(\mathrm{I})$ INCREMENT

$570 \mathrm{X}(\mathrm{I})=\mathrm{X}(\mathrm{I})+\mathrm{DXJ}$

580 GOSUB 1410 'EQUATIONS TO BE SOLVED IN F(I,J)=F(X,T)

590 FOR L $=1$ TO N

$600 \mathrm{~A}(\mathrm{~L}, \mathrm{I})=(\mathrm{F}(\mathrm{L}, 2)-\mathrm{F}(\mathrm{L}, 1)) / \mathrm{DXJ} *\left(-\mathrm{H}^{*} \mathrm{~A} 1\right)$ 'JACOBIAN *(-H*A)

$610 \mathrm{~A}(\mathrm{~L}, \mathrm{I})=\mathrm{D}(\mathrm{L}, \mathrm{I})+\mathrm{A}(\mathrm{L}, \mathrm{I})$ 'FINAL COEFFICIENT MATRIX

620 NEXT L

$630 \mathrm{X}(\mathrm{I})=\mathrm{X}(\mathrm{I})$-DXJ 'RESTORE TO ITS ORIGINAL VALUE

610 NEXT I

650 'CALCULATE AK1(I) AND NEW X(I) FOR THE SECOND MATRIX 660 GOSUB 1460 'LU DECOMPOSITION SUBROUTINE 670 FOR $\mathrm{I}=1$ TO N 
$680 \wedge \mathrm{K} 1(\mathrm{I})=\mathrm{C}(\mathrm{I})$ ' SOLUTIONS FOR AK1(I)

$690 \times P(I)=X(I)$ 'STORE THE ORIGINAL X(I) IN XP(I)

$700 \mathrm{X}(\mathrm{I})=\mathrm{XP}(\mathrm{I})+\mathrm{B} 2 * \mathrm{AKI}(\mathrm{I})$ 'FOR SECOND B MATRIX CALCULATION

710 NEXT I

720 'CALCULATE THE SECOND B MATRIX

$730 \mathrm{~J}=1$

740 GOSUB 1410 'EQUATION SUBROUTINE, F(I,J)=F(X,T)

750 FOR $\mathrm{I}=1$ TO N

$760 \mathrm{~B}(\mathrm{I})=\mathrm{F}(\mathrm{I}, 1) * \mathrm{H}$ 'SECOND B MATRIX

770 NEXT I

780 'CALCULATE AK2(I) AND THE THIRD B MATRIX

790 GOSUB 2080 'LATER PART OF LU DECOMPOSITION SUBROUTINE 800 FOR I $=1$ TO N

$\$ 10 \mathrm{~B}(\mathrm{I})=0$ 'INITIALIZE FOR THE THIRD B MATRIX

820 AK2(I) $=\mathrm{C}(\mathrm{I})$ 'SOLUTION FOR AK2(I)

830 FOR $\mathrm{K}=1$ TO N

$840 \mathrm{~B}(\mathrm{I})=\mathrm{B}(\mathrm{I})+\mathrm{D}(\mathrm{I}, \mathrm{K}) *(\mathrm{~B} 31 * \mathrm{AK} 1(\mathrm{~K})+\mathrm{B} 32 * \mathrm{AK} 2(\mathrm{~K}))$ 'ALPHA MATRIX IN THE TEXT

850 NEXT K

860 NEXT I

870 'CALCULATE AK3(I) AND NEW X(I)

980 GOSUB 2080 'LATER PART OF LU DECOMPOSITION SUBROUTINE 890 FOR $\mathrm{I}=1$ TO N

900 AK3(I) $=\mathrm{C}(\mathrm{I})$ 'SOLUTION FOR AK3(I)

$910 \mathrm{X}(\mathrm{I})=\mathrm{XP}(\mathrm{I})+\mathrm{R} 1 * \mathrm{AK} 1(\mathrm{I})+\mathrm{R} 2 * \mathrm{AK} 2(\mathrm{I})+\mathrm{AK} 3(\mathrm{I})$

920 NEXT I

$930 \mathrm{~T}=\mathrm{T}+\mathrm{H}$ 'NEW TIME

$940 \mathrm{IF} \mathrm{T}<=0$ THEN TE$=0$ ELSE TE $=\mathrm{TE}+\mathrm{AKG} * \mathrm{AREA} * \mathrm{X}(2) / \mathrm{APT}{ }^{*} 17 * \mathrm{H}-$

$\mathrm{E} * \mathrm{C} 2 * 17 * \mathrm{H}$ 'TOTAL AMMONIA EVAPORATED INTO VAPOR LINE IN

LBS

950 APPMT $=X(1) * 18 / 62.4 * 1000000$ ! 'TOTAL AMMONIUM ION IN PPM

960 APPMF $=62.4 / 18 * X(3) * 17 / 62.4 * 1000000$ ! 'PPM OF FREE AMMONIA

970 APHC $=0$ 'NULL PH WHEN THERE IS NO CONDENSATE

980 IF $(\mathrm{T}>=30)$ AND $(\mathrm{T}<=42)$ THEN $\mathrm{E}=60: \mathrm{TEMP}=212$

$990 \mathrm{IF}(\mathrm{T}>42)$ AND $(\mathrm{T}<=58)$ THEN $\mathrm{E}=66.75: \mathrm{TEMP}=212$

1000 'IF $(\mathrm{T}<30)$ AND $(\mathrm{T}>53)$ THEN $\mathrm{E}=0$

$1010 \mathrm{IF} \mathrm{T}>=74$ THEN $\mathrm{V}=240.3: \mathrm{TEMP}=104$

1020 IF $(\mathrm{T}>=15)$ AND $(\mathrm{T}<=17)$ THEN $\mathrm{V}=240.3+(1041.3-240.3) / 2 *(\mathrm{~T}$ -

15) $: \mathrm{CF}=.00104$

1030 IF $(T>42)$ AND $(T<58)$ THEN DV $=-E^{*} H$ ELSE DV $=0$

1040 IF $(\mathrm{T}>42)$ AND $(\mathrm{T}<58)$ THEN FR $=66.75: \mathrm{CF}=.0052$ 
$1050 \mathrm{IF}(\mathrm{T}>=30)$ AND $(\mathrm{T}<=42)$ THEN IR=1 ELSE IR=0'IR=1 WHEN REFLUXING

1060 IF $(\mathrm{T}>=17)$ AND $(\mathrm{T}<=30)$ THEN TEMP $=203$

1070 IF $(\mathrm{T}>=58)$ AND $(\mathrm{T}<=62)$ THEN TEMP $=212-(212-104) / 4 *(\mathrm{~T}-58)$

1080 IF $(\mathrm{T}>=15)$ AND ( $\mathrm{T}<=17)$ THEN APH $=12: \mathrm{FR}=400.5$

1090 IF $(\mathrm{T}>=17)$ AND $(\mathrm{T}<=21)$ THEN $\mathrm{V}=1041.3+(1068-1041.3) / 4 *(\mathrm{~T}$ -

15) : $\mathrm{APH}=12-(12-5) / 4 *(\mathrm{~T}-17)$

$1100 \mathrm{IF}(\mathrm{T}>=21)$ AND $(\mathrm{T}<=74)$ THEN $\mathrm{V}=1068$

$1110 \mathrm{IF}(\mathrm{T}>=21)$ AND $(\mathrm{T}<=30)$ THEN APH $=5$

1120 IF $(\mathrm{T}>=30)$ AND $(\mathrm{T}<=36)$ THEN APH $=5+(7-5) / 6 *(\mathrm{~T}-30)$

1130 IF $(\mathrm{T}>=42)$ AND $(\mathrm{T}<=74)$ THEN APH $=8$

1140 IF $\mathrm{T}>74$ THEN $\mathrm{APH}=8$

1150 IF ( $\mathrm{T}>17)$ AND $(\mathrm{T}<=42)$ THEN $\mathrm{CF}=0$

1160 IF $\mathrm{T}>58$ THEN $\mathrm{CF}=0$

1170 IF (T $>=17)$ AND $(\mathrm{T}<=42)$ THEN FR=0

1180 IF $\mathrm{T}>=58$ THEN FR $=0: \mathrm{CF}=0: \mathrm{E}=0$

1190 IF $(\mathrm{T}>=36)$ AND $(\mathrm{T}<=42)$ THEN APH $=7$

1200 IF $(\mathrm{T}>=62)$ AND $(\mathrm{T}<=74)$ THEN TEMP $=104$

1210 'IF $\mathrm{T}<=5$ THEN APH $=12$

1220 'IF T $>=5$ THEN APH $=\mathrm{APH}+(5-12) / 5 *^{*} \mathrm{H}$

1.230 'IF APH $<5$ THEN APH $=5$

1240 APKB $=5.2209-.24448 / 2.303 *$ LOG(TEMP) ' PKB OF AMMONIA AS A FUNCTION OF TEMP

1250 APS $=$ APKB + APH -14

1260 IF IR $=0$ AND $T<=0$ THEN $V=V$ ELSE $V=V+D V^{\prime} V O L U M E$ OF SRAT AT ANY INSTANT IN FT^3

1261 APKB $=5.2209-.24448 / 2.303 *$ LOG(TEMP) ' PKB OF AMMONIA IN THE SRAT

1262 AH $=137.84 * 10^{\wedge}(.009622 *$ TEMP) 'HENRY'S C'ONSTANT MMHG IN THE SRAT

1263 BETA $=1 /(460+$ TEMP $)$ 'IDEAL GAS EXPANSION COEFFICIENT

1264 GR $=G^{*}$ BETA $*($ TEMP-TA $) *$ DIA $^{\wedge} 3 * Z^{*} O^{\wedge}{ }^{\wedge} 2 /$ UG $^{\wedge} 2$ 'GRASOF NUMBER

$1265 \mathrm{HC}=\mathrm{AK} / \mathrm{DIA} * .15^{*}\left(\mathrm{GR}^{*} .69\right)^{\wedge}(1 / 3)$ 'HEAT TRANSFER COEFFICIENT

$\mathrm{BTU} / \mathrm{FT} / \mathrm{HR} / \mathrm{oF}$

1266 APS $=$ APKB + APH -14

$1267 \mathrm{AKG}=.2661 *$ HC'MASS TRANSFER COEFFICIENT LB-

MOLE/FT^2/HR

1270 IF ABS(212-TEMP)<1 THEN GOSUB 2370

1280 PRINT USING A\$; T,APPMT,TE,APH ,V,TEMP,APHC

1281 PRINT \#1,T,APPMT,TE,APH,V,TEMP,APHC

1290 'PRINT " $\mathrm{T}=" ; \mathrm{T}$,

1300 'FOR $\mathrm{I}=1$ TO N

1310 'PRINT "X(";I;")=";X(I), 


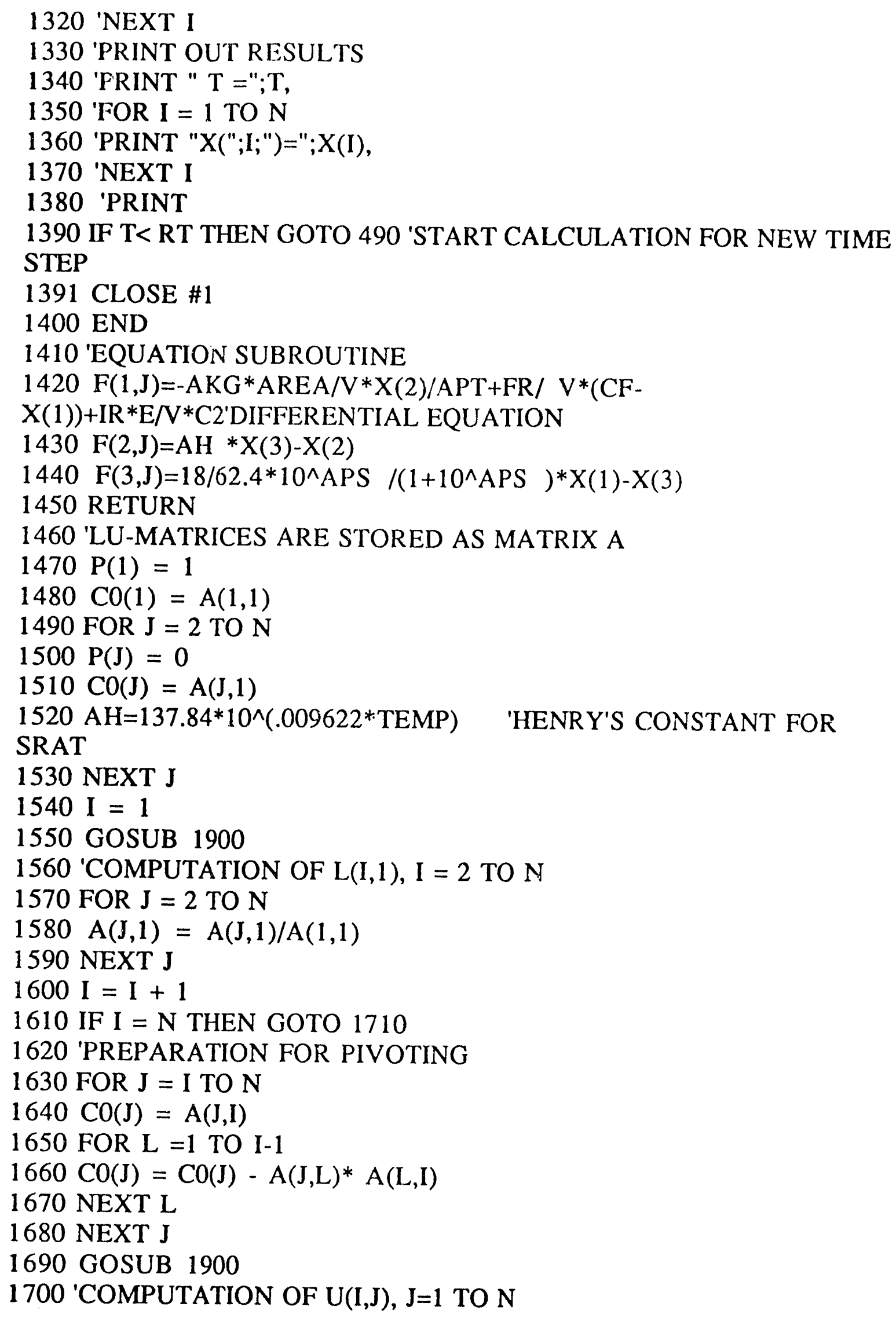




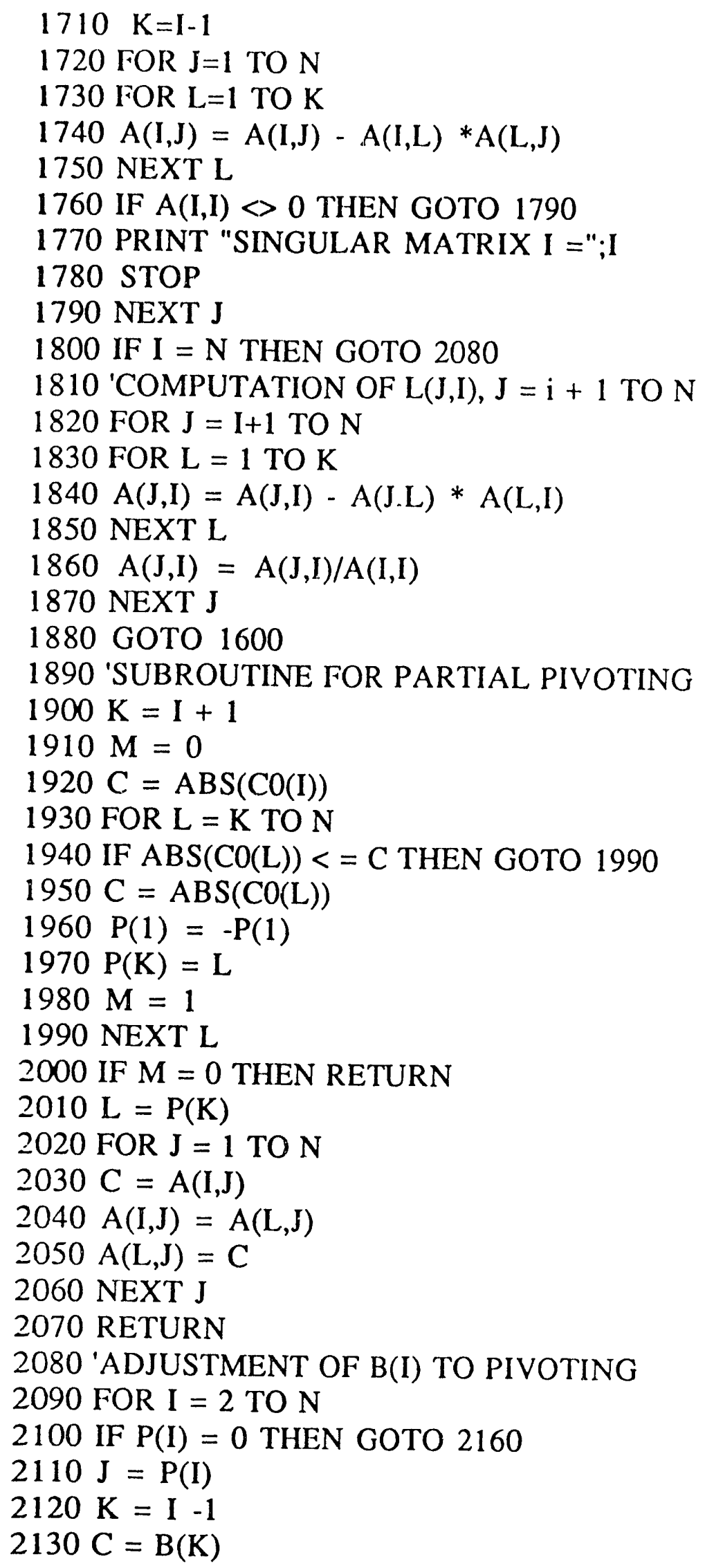


$2140 \mathrm{~B}(\mathrm{~K})=\mathrm{B}(\mathrm{J})$

$2150 \mathrm{~B}(\mathrm{~J})=\mathrm{C}$

2160 NEXT I

2170 'SOLUTION OF THE FIRST TRIANGULAR SYSTEM

2180 'VECTOR Y IS STORED AS VECTOR B

2190 FOR $\mathrm{I}=2 \mathrm{TO} \mathrm{N}$

$2200 \mathrm{~K}=\mathrm{I}-1$

2210 FOR $\mathrm{J}=1$ TO $\mathrm{K}$

$2220 \mathrm{~B}(\mathrm{I})=\mathrm{B}(\mathrm{I})-\mathrm{A}(\mathrm{I}, \mathrm{J}) * \mathrm{~B}(\mathrm{~J})$

2230 NEXT $J$

2240 NEXT I

2250 'SOLUTION OF THE SECOND TRIANGUL.AR SYSTEM

$2260 \mathrm{C}(\mathrm{N})=\mathrm{B}(\mathrm{N}) / \mathrm{A}(\mathrm{N}, \mathrm{N})$

$2270 \mathrm{M}=\mathrm{N}-1$

2280 FOR I $=$ M TO 1 STEP -1

$2290 \mathrm{~K}=\mathrm{I}+1$

$2300 \mathrm{C}(\mathrm{I})=\mathrm{B}(\mathrm{I})$

2310 FOR $\mathrm{J}=\mathrm{K}$ TO N

$2320 \mathrm{C}(\mathrm{I})=\mathrm{C}(\mathrm{I})-\mathrm{A}(\mathrm{I}, \mathrm{J}) * \mathrm{C}(\mathrm{J})$

2330 NEXT $\mathbf{J}$

$2340 \mathrm{C}(\mathrm{I})=\mathrm{C}(\mathrm{I}) / \mathrm{A}(\mathrm{I}, \mathrm{I})$

2350 NEXT I

2360 RETURN

2370 'CALCULATE CONDENSATE WHEN THE SRAT IS BOILING

$2380 \mathrm{C} 2=\mathrm{AKG} * \mathrm{AREA} * \mathrm{X}(2) / \mathrm{APT} /(\mathrm{E}+\mathrm{AIR} * 18 / 62.4 * \mathrm{AHP} / \mathrm{APT}))^{\prime} \mathrm{TOT}$ AL

AMMONIUM ION CONC. IN THE CONDENSATE, LB-MOLE/f^ $\wedge 3$

$2390 \mathrm{Y}=\left(-10^{\wedge}(-\mathrm{APKBP})+\mathrm{SQR}\left(\left(10^{\wedge}\left(-2^{*} \mathrm{APKBP}\right)+4 * 10^{\wedge}(-\mathrm{APKBP}) * \mathrm{C} 2\right)\right)\right) / 2$

'FREE [OH] IN LB-MOLE/FT^3

$2400 \mathrm{YM}=\mathrm{Y}^{*} 453.6 /\left(3.048^{\wedge} 3\right)$ ' $[\mathrm{OH}]$ IN MOLAR

2410 APHC $=14+1 / 2.303 *$ LOG(YM) 'PH OF CONDENSATE

2420 RETURN 


\section{APPENDIX III: BASIC PROGRAM FOR NH3 VOLATILITY IN}

SME

10 'THIS PROGRAM CALCULATE AMMONIA VOLATILITY RATE 20 'ALL UNITS ARE BRITISH UNITS EXCEPT PRESSURE IN $\mathrm{mmHg}$

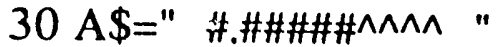

40 DEFINT I-P

$50 \mathrm{~N}=3$ 'TOTAL NUMBER OF EQUATION

60 'DEFINT I-P : DEFDBL A-H,Q-Z

70 DIM

$A(N, N), B(N), C(N), D(N, N), C O(N), P(N), X(N), X P(N), A K 1(N), A K 2(N), A K 3(N), F$ $(\mathrm{N}, 2)$

71 OPEN "O", \#1, "SMEDATA"

$S 0$ 'READ IN THE PROCESS VARIABLES

90 'PH; TOTAL AMMONIA,PPM; SOLUTION TEMP, oF; TANK

DIAMETER, FT; TOTAL PRESSURE, MMHG; SOLUTION VOLUME, FT^3;

COND. TEMP, oF; AIR PURGE, LB-MOLE/HR; LP

100 READ APH ,APPMT0,TEMP,DIA,APT,V,TEMPP, AIR,LP

110 DATA 9, $6,104,12,74 j, 1041.3,104,10.1,0$

$120 \mathrm{E}=0$ 'EVAPORATION RATE FT^3/HR

$130 \mathrm{FR}=0$ 'FLOW RATE FT^3/HR

$140 \mathrm{CF}=0$ 'CONC OF TOTAL AMMONIUM IN THE FEED LB-MOLE/FT^3 150 'CALCULATE PROCESS PROPERTIES

160 APKB $=5.2209-.24448 / 2.303 *$ LOG(TEMP) ' PKB OF AMMONIA IN THE SRAT

170 APKBP=5.2209-.24448/2.303*LOG(TEMPP) ' PKB OF AMMONIA LV THE CONDENSER

$180 \mathrm{AH}=137.84 * 10^{\wedge}(.009622 *$ TEMP) 'HENRY'S CONSTANT MMHG IN THE SRAT

190 AHP $=137.84 * 10^{\wedge}(.009622 *$ TEMPP $)$ 'HENRY'S CONSTANT IN CONDENSER MMHG

$200 \mathrm{G}=32.2 * 3600 * 3600$ 'GRAVITATIONAL ACCELERATION CONSTANT $\mathrm{FT} / \mathrm{HR} / \mathrm{HR}$

210 BETA $=1 /(460+$ TEMP) 'IDEAL GAS EXPANSION COEFFICIENT

$220 \mathrm{TA}=65$ 'AIR TEMPERATURE oF

$230 \mathrm{ZOG}=29 / 359 * 492 /(\mathrm{TA}+460) * A P T / 760$ 'AIR DENSITY LB/FT^3

$240 \mathrm{UG}=.04356^{*}((\mathrm{TA}+460) /(460+100))^{\wedge} .5$ 'AIR VISCOSITY 0.04356

L.B/FT/HR AT 100 oF

$250 \mathrm{APR}=.69^{\prime}$ AIR PRANDTL NUMBER

$260 \mathrm{SC}=.61$ 'SCHMIDT NUMBER FOR AMMONIA IN AIR

$270 \mathrm{CP}=.24$ 'SPECIFIC HEAT OF AIR BTU/LB/OF

$280 \mathrm{AK}=.014 *((\mathrm{TA}+460) /(460+32)) \wedge .5$ 'AIR THERMOCONDUCTIVITY BTU/HR/FT/oF 
290 AREA $=3.14 *$ DIA*DIA 4 ' SOLUTION SURFACE AREA, FT^2 $300 \mathrm{GR}=\mathrm{G}^{*} \mathrm{BETA} *(\mathrm{TEMP}-\mathrm{TA}) * \mathrm{DIA}^{\wedge}{ }^{\wedge}{ }^{\prime} \mathrm{ZOG}^{\wedge}$ $2 / \mathrm{UG}^{\wedge} 2$ 'GRASOF NUMBER $310 \mathrm{HC}=\mathrm{AK} / \mathrm{DIA} * .15^{*}\left(\mathrm{GR}^{*} .69\right)^{\wedge}(1 / 3)$ 'HEAT TRANSFER COEFFICIENT BTU/FT/HR/oF 320 APS $=\mathrm{APKB}+\mathrm{APH}-14$

$330 \mathrm{X}(1)=\mathrm{APPMT} 0 / 1000000 ! * 62.4 / 18 \quad \mathrm{lb}-\mathrm{mole} / \mathrm{ft} \mathrm{f}^{\wedge} \mathrm{3}$ total ammonium $340 \mathrm{X}(3)=18 / 62.4 * 10^{\wedge}$ APS $/\left(1+10^{\wedge}\right.$ APS $) * X(1)^{\prime}$ MOLE FRACTION OF FREE AMMONIA $350 \mathrm{X}(2)=\mathrm{AH} * \mathrm{X}(3)^{\prime}$ VAPOR PRESSURE OF AMMONIA IN IN SRAT IN MMHG 360 AKG $=.2661 *{ }^{*} C^{\prime}$ MASS TRANSFER COEFFICIENT LB-MOLE/FT^2/HR 370 PRINT " LBS AMMONIA CONDENSATE PH

380 PRINT " TIME. HR PPMT EVAPORATED VAPOR LINE 390 'INPUT INITIAL CONDITIONS, STEP SIZE AND TIME LIMIT $400 \mathrm{~T}=0: \mathrm{H}=.5: \mathrm{RT}=92$

410 'INPUT BASIC CONSTANTS FOR GSIRK

$420 \mathrm{~A} 1=.435867: \mathrm{B} 2=.75: \mathrm{B} 31=-.630172: \mathrm{B} 32=-.24235:$

$\mathrm{R} 1=1.03758: \mathrm{R} 2=.83494$

430 'INPUT D MATRIX

$440 \quad D(1,1)=1$

$4500^{\prime}$

$460^{\prime}$

$470^{\prime}$

480 GOTO 940 'PRINT OUT INITIAL CONDITIONS

490 'CALCULATE FIRST B MATRIX AND JACOBIAN

$500 \mathrm{~J}=1$

510 GOSUB 1410 'EQUATIONS TO BE SOLVED IN F(I,J)=F(X,T)

$520 \mathrm{~J}=2$

530 FOR I $=1$ TO N

$540 \mathrm{~B}(\mathrm{I})=\mathrm{F}(\mathrm{I}, 1) * \mathrm{H}$ 'THE FIRST B MATRIX

$550 \mathrm{DXJ}=\mathrm{X}(\mathrm{I}) * .0001$ ' $\mathrm{X}(\mathrm{I})$ INCREMENT

$560 \mathrm{IF}$ DXJ $=0$ THEN DXJ $=.00001$ 'ALTERNATE X(I) INCREMENT

$570 \mathrm{X}(\mathrm{I})=\mathrm{X}(\mathrm{I})+\mathrm{DX} . \mathrm{I}$

580 GOSUB 1410 'EQUATIONS TO BE SOLVED IN $F(I, J)=F(X, T)$

590 FOR L $=1$ TO N

$600 \mathrm{~A}(\mathrm{~L}, \mathrm{I})=(\mathrm{F}(\mathrm{L}, 2)-\mathrm{F}(\mathrm{L}, 1)) / \mathrm{DXJ} *\left(-\mathrm{H}^{*} \mathrm{~A} 1\right)$ 'JACOBIAN * $\left(-\mathrm{H}^{*} \mathrm{~A}\right)$

$610 \mathrm{~A}(\mathrm{~L}, \mathrm{I})=\mathrm{D}(\mathrm{L}, \mathrm{I})+\mathrm{A}(\mathrm{L}, \mathrm{I})$ 'FINAL COEFFICIENT MATRIX

620 NEXT L

$630 X(\mathrm{I})=\mathrm{X}(\mathrm{I})$-DXJ 'RESTORE TO ITS ORIGINAL VALUE

640 NEXT I

650 'CALCULATE AK1(I) AND NEW X(I) FOR THE SECOND MATRIX 660 GOSUB 1460 'LU DECOMPOSITION SUBROUTINE 
670 FOR $I=1$ TO N

$680 \mathrm{AK} 1(\mathrm{I})=\mathrm{C}(\mathrm{I})$ ' SOLU'TIONS FOR AK1(I)

$690 \times \mathrm{X}(\mathrm{I})=\mathrm{X}(\mathrm{I})$ 'STORE THE ORIGINAL X(I) IN XP(I)

$700 \mathrm{X}(\mathrm{I})=\mathrm{XP}(\mathrm{I})+\mathrm{B} 2 * A \mathrm{~A} 1(\mathrm{I})$ 'FOR SECOND B MATRIX CALCULATION

710 NEXT I

720 'CALCULATE THE SECOND B MATRIX

$730 \mathrm{~J}=1$

740 GOSUB 1410 'EQUATION SUBROUTINE, $F(I, J)=F(X, T)$

750 FOR I = 1 TO N

$760 \mathrm{~B}(\mathrm{I})=\mathrm{F}(\mathrm{I}, 1) * \mathrm{H}$ 'SECOND B MATRIX

770 NEXT I

780 'CALCULATE AK2(I) AND THE THIRD B MATRIX

790 GOSUB 2080 'LATER PART OF LU DECOMPOSITION SUBROUTINE

800 FOR I $=1$ TO N

$810 \mathrm{~B}(\mathrm{I})=0$ 'INITIALIZE FOR THE THIRD B MATRIX

820 AK2(I) $=\mathrm{C}(\mathrm{I})$ 'SOLUTION FOR AK2(I)

830 FOR $\mathrm{K}=1$ TO N

$840 \mathrm{~B}(\mathrm{I})=\mathrm{B}(\mathrm{I})+\mathrm{D}(\mathrm{I}, \mathrm{K}) *(\mathrm{~B} 31 * \mathrm{AK} 1(\mathrm{~K})+\mathrm{B} 32 * \mathrm{AK} 2(\mathrm{~K}))$ 'ALPHA MATRIX IN THE TEXT

850 NEXT K

860 NEXT I

870 'CALCULATE AK3(I) AND NEW X(I)

880 GOSUB 2080 'LATER PART OF LU DECOMPOSITION SUBROUTINE 890 FOR I $=1$ TO N

900 AK3(I) $=\mathrm{C}(\mathrm{I})$ 'SOLUTION FOR AK3(I)

$910 \mathrm{X}(\mathrm{I})=\mathrm{XP}(\mathrm{I})+\mathrm{R} 1 * \mathrm{AK} 1(\mathrm{I})+\mathrm{R} 2 * \mathrm{AK} 2(\mathrm{I})+\mathrm{AK} 3(\mathrm{I})$

920 NEXT I

$930 \mathrm{~T}=\mathrm{T}+\mathrm{H}$ 'NEW TIME

$940 \mathrm{IF}$ T $<=0$ THEN TE $=0$ ELSE TE $=\mathrm{TE}+\mathrm{AKG} * \mathrm{AREA} * \mathrm{X}(2) / \mathrm{APT} * 17 * \mathrm{H}-$

$\mathrm{E}^{*} \mathrm{C} 2 * 17 * \mathrm{H}$ 'TOTAL AMMONIA EVAPORATED INTO VAPOR LINE IN LBS

950 APPMT $=X(1) * 18 / 62.4 * 1000000$ ! 'TOTAL AMMONIUM ION IN PPM

960 APPMF $=62.4 / 18 * X(3) * 17 / 62.4 * 1000000$ ! 'PPM OF FREE AMMONIA

970 APHC $=0$ 'NULL PH WHEN THERE IS NO CONDENSATE

971 IF $\mathrm{T}=7$ THEN

$X(1)=(X(1) * 240.3+(960 / 1000000 ! * 62.4 / 18) *(1041.3-240.3)) / 1041.3$

$980 \mathrm{IF}(\mathrm{T}>=7)$ AND $(\mathrm{T}<=52)$ THEN $\mathrm{E}=10.853: \mathrm{TEMP}=212$

990 IF $(\mathrm{T}>7)$ AND $(\mathrm{T}<=52)$ THEN $\mathrm{V}=1041.3-(1041.3-552.93) / 45 *(\mathrm{~T}-7)$

$: \mathrm{IR}=0$

1000 IF $(\mathrm{T}>=52)$ THEN $V=240.3:$ TEMP $=104: E=0: I R=0$ 
1240 APKB $=5.2209-.24448 / 2.303 *$ LOG(TEMP) ' PKB OF AMMONIA AS A FUNCTION OF TEMP

$1250 \mathrm{APS}=\mathrm{APKB}+\mathrm{APH}-14$

1260 IF IR=0 AND $T<=0$ THEN $V=V$ ELSE $V=V+D V ' V O L U M E$ OF SRAT

AT ANY INSTANT IN FT^3

1261 APKB $=5.2209-.24448 / 2.303 *$ LOG(TEMP) ' PKB OF AMMONIA IN THE SRAT

$1262 \mathrm{AH}=137.84 * 10^{\wedge}(.009622 *$ TEMP) 'HENRY'S CONSTANT MMHG IN THE SRAT

1263 BETA $=1 /(460+$ TEMP) 'IDEAL GAS EXPANSION COEFFICIENT $1264 \mathrm{GR}=\mathrm{G}^{*} \mathrm{BETA}^{*}(\mathrm{TEMP}-\mathrm{TA}) * \mathrm{DIA}^{\wedge}{ }^{\wedge}{ }^{*} \mathrm{ZOG}^{\wedge} 2 / \mathrm{UG}^{\wedge}{ }^{\wedge}$ 'GRASOF NUMBER $1265 \mathrm{HC}=\mathrm{AK} / \mathrm{DIA} * .15 *\left(\mathrm{GR}^{*} .69\right)^{\wedge}(1 / 3)$ 'HEAT TRANSFER COEFFICIENT $\mathrm{BTU} / \mathrm{FT} / \mathrm{HR} / \mathrm{OF}$

1266 APS $=$ APKB + APH -14

$1267 \mathrm{AKG}=.2661 * \mathrm{HC}$ MASS TRANSFER COEFFICIENT LB-

MOLE/FT^2/HR

1270 IF ABS(212-TEMP)<1 THEN GOSUB 2370

1280 PRINT USING A\$; T,APPMT,TE,APH ,V,TEMP,APHC

1281 PRIINT \#1, T,APPMT,TE,APH,V,TEMP,APHC

1290 'PRINT " $\mathrm{T}=$ =; $\mathrm{T}$,

1300 'FOR I = 1 TO N

1310 'PRINT "X(";I;")=";X(I),

1320 'NEXT I

1330 'PRINT OUT RESULTS

1340 'PRINT " $\mathrm{T}=$ ="; $\mathrm{T}$,

1350 'FOR I $=1$ TO N

1360 'PRINT "X(";I;")=";X(I),

1370 'NEXT I

1380 'PRINT

1390 IF T< RT THEN GOTO 490 'START CALCULATION FOR NEW TIME STEP

1391 CLOSE \#1

1400 END

1410 'EQUATION SUBROUTINE

$1420 \mathrm{~F}(1, \mathrm{~J})=-\mathrm{AKG} * \mathrm{AREA} / \mathrm{V} * \mathrm{X}(2) / \mathrm{APT}+\mathrm{FR} / \mathrm{V} *(\mathrm{CF}-$

$\mathrm{X}(1))+\mathrm{IR} * \mathrm{E} / \mathrm{V}^{*} \mathrm{C} 2$ 'DIFFERENTIAL EQUATION

$1430 \mathrm{~F}(2, \mathrm{~J})=\mathrm{AH} * \mathrm{X}(3)-\mathrm{X}(2)$

$1440 \mathrm{~F}(3, \mathrm{~J})=18 / 62.4 * 10^{\wedge} \mathrm{APS} /\left(1+10^{\wedge} \mathrm{APS}\right) * \mathrm{X}(1)-\mathrm{X}(3)$

1450 RETURN

1460 'LU-MATRICES ARE STORED AS MATRIX A

$1470 \mathrm{P}(1)=1$

$1480 \mathrm{CO}(1)=\mathrm{A}(1,1)$

1490 FOR $\mathrm{J}=2 \mathrm{TO} \mathrm{N}$ 


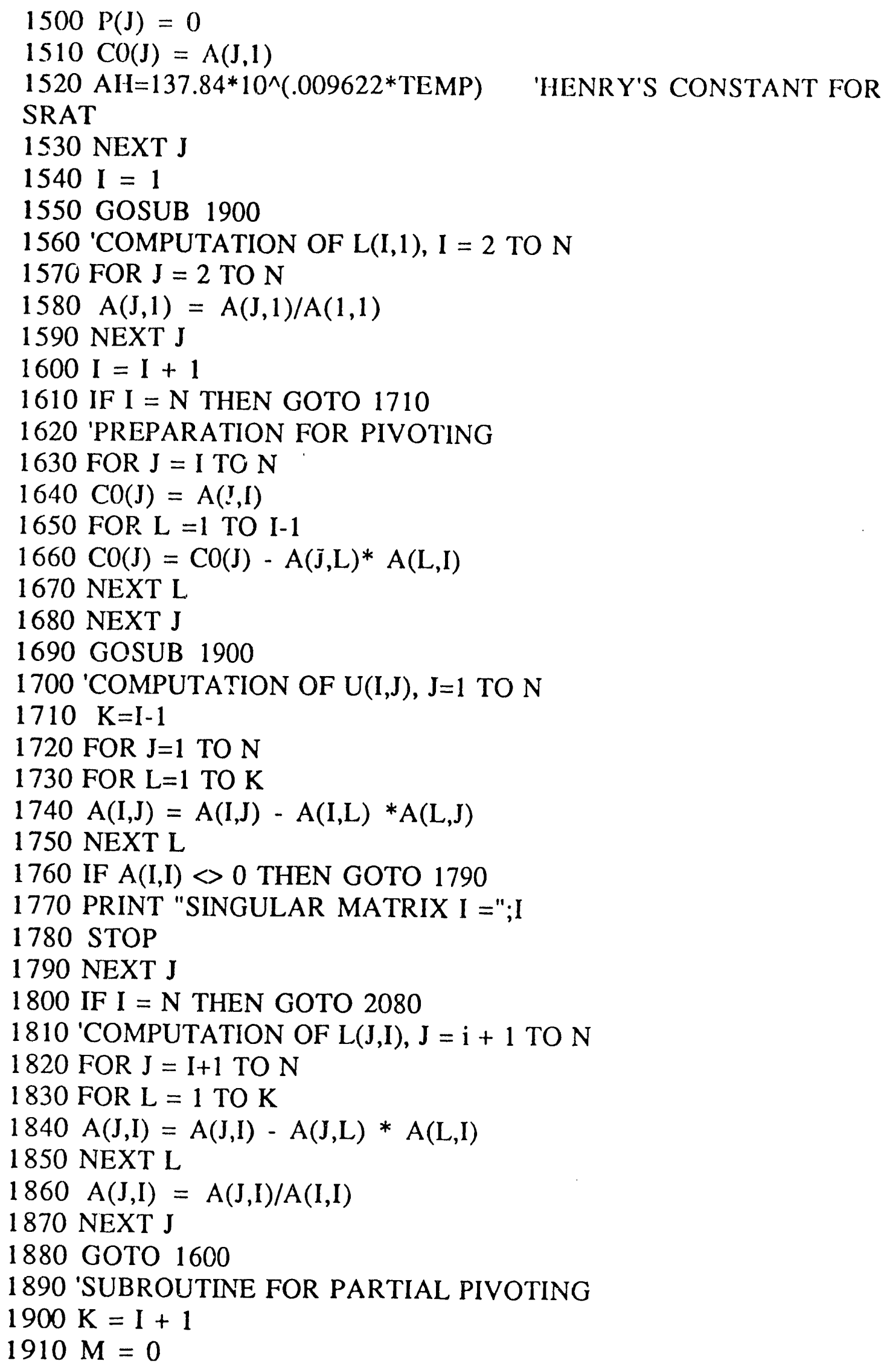


2350 NEXT I

2360 RETURN

2370 'CALCULATE CONDENSATE WHEN THE SRAT IS BOILING

$2380 \mathrm{C} 2=\mathrm{AKG} * \mathrm{AREA} * \mathrm{X}(2) / \mathrm{AP} T /(\mathrm{E}+\mathrm{AIR} * 18 / 62.4 * \mathrm{AHP} / \mathrm{APT})^{\prime} \mathrm{TOTAL}$

AMMONIUM ION CONC. IN THE CONDENSATE, LE-MOLE/ft^ 3

$2390 \mathrm{Y}=\left(-10^{\wedge}(-\mathrm{APKBP})+\mathrm{SQR}\left(\left(10^{\wedge}(-2 * \mathrm{APKBP})+4 * 10^{\wedge}(-\mathrm{APKBP}) * \mathrm{C} 2\right)\right)\right) / 2$

'FREE [OH] IN LB-MOLE/FT^3

$\left.2400 \mathrm{YM}=\mathrm{Y}^{*} 453.6 /\left(3.048^{\wedge} 3\right)\right)^{\prime}[\mathrm{OH}] \mathrm{IN}$ MOLAR

2410 APHC $=14+1 / 2.303 *$ LOG(YM) 'PH OF CONDENSATE

2420 RETUR.N 


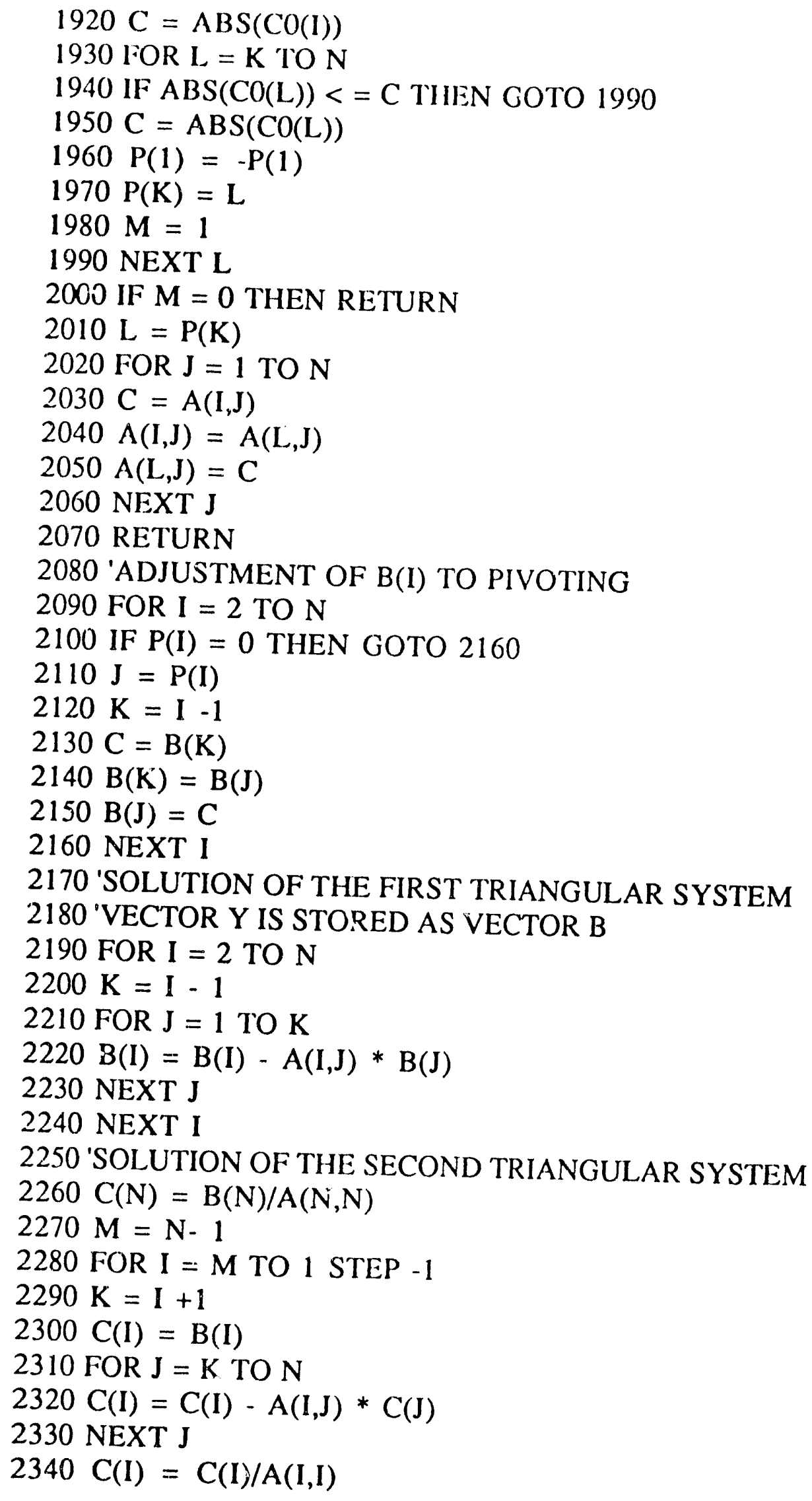



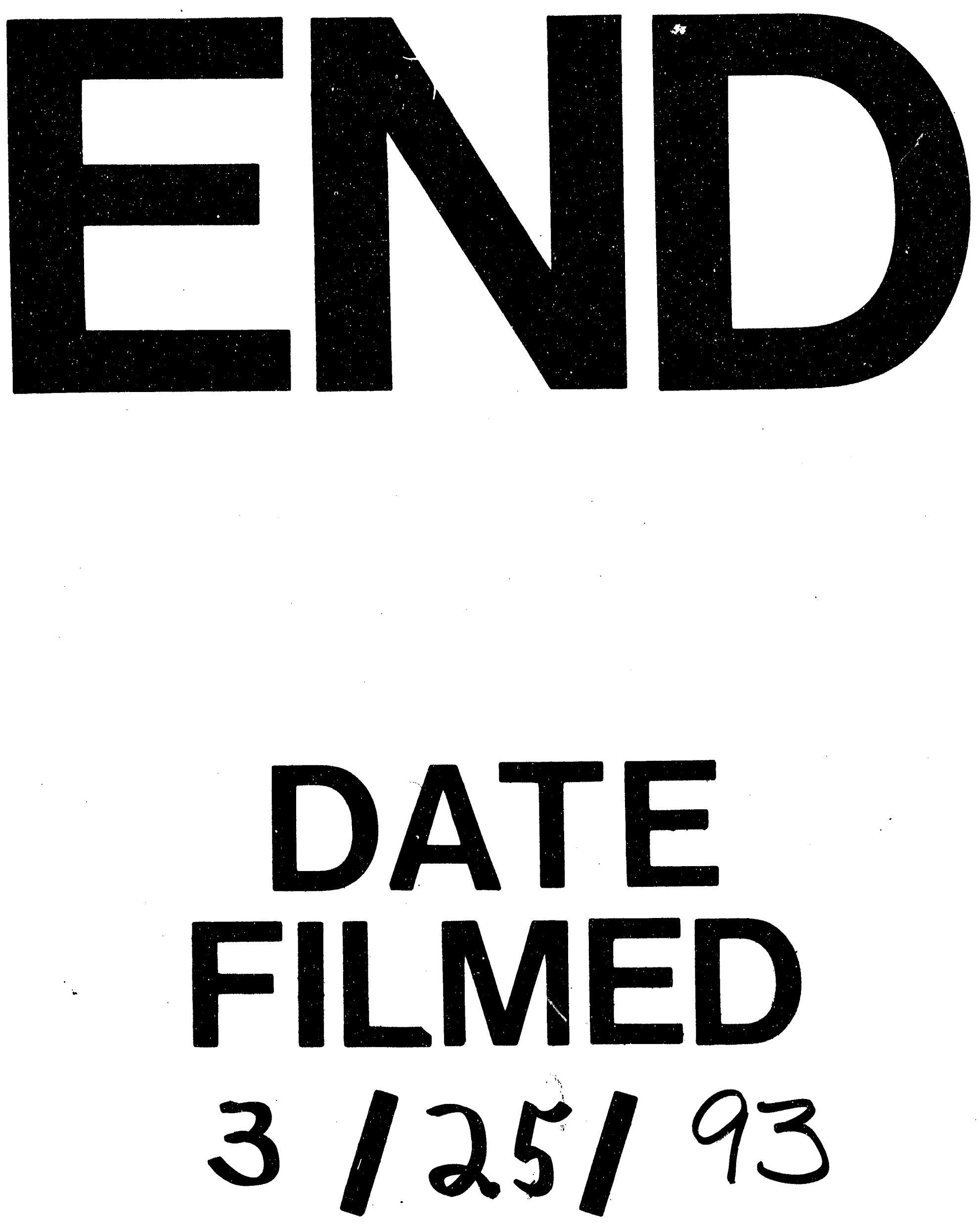

| 
